\title{
Nowe możliwości \\ wytwarzania powłokowych barier cieplnych metodą natryskiwania plazmowego z zawiesin
}

\author{
The new possibilities for the production \\ of Thermal Barrier Coatings by Suspension Plasma Spraying
}

\section{Streszczenie}

Powłokowe bariery cieplne (Thermal Barrier Coatings) są zaawansowanymi systemami materiałowymi, których głównych zadaniem jest ochrona powierzchni metalicznych, np. w turbinach lotniczych, przed obciążeniami cieplnymi. Jednym z najważniejszych elementów tego układu jest zewnętrzna powłoka ceramiczna, która ze względu na małą przewodność cieplną oraz wysoką temperaturę topnienia umożliwia obniżenie profilu temperatury na przekroju elementów do wartości dopuszczalnych przez pozostałe materiały. Kluczowym zagadnieniem pozostaje możliwość wytwarzania omawianych powłok w sposób ekonomiczny oraz jednocześnie przy zachowaniu korzystnej struktury powłok gwarantującej zachowanie odpowiednich właściwości użytkowych. W badaniach przeprowadzono złożony plan eksperymentu natryskiwania powłok z uwzględnieniem różnych zmiennych w procesie: (i) prędkości liniowej palnika, (ii) odległości natryskiwania, (iii) zawartości fazy stałej w zawiesinie oraz (iv) sposobu przygotowania podłoża. W procesie natryskiwania użyto zawiesin na bazie dwóch różnych proszków tlenku cyrkonu: częściowo, oraz w pełni, stabilizowanego tlenkiem itru; oba są obecnie powszechnie stosowane w przemyśle. Na podstawie przeprowadzonych badań ich mikrostruktury dokonano oceny, czy metoda natryskiwania plazmowego z zawiesin, w perspektywie kolejnych lat, może stanowić alternatywę dla obecnie używanych metod do wytwarzanie powłokowych barier cieplnych.

Słowa kluczowe: natryskiwanie plazmowe z zawiesin, powłokowe bariery cieplne, stabilizowane tlenek cyrkonu, mikrostruktura

\section{Abstract}

Thermal Barrier Coatings are advanced multi-material systems whose main goal is to protect metallic surfaces against thermal loads, like for example blades in gas turbines. One of the most important elements of TBC system is the ceramic top layer. Due to the low thermal conductivity and a high melting point it allows reducing the temperature profile measured on the crosssection of the element below the limit values for all used materials. The key issue is the ability to produce coatings in an economical way and maintaining a microstructure of coatings guaranteeing the preservation of proper properties at the same time. In the presented studies the complex spray process was conducted. Design of spray experiment was made taking into account the different variables in the process: (i) the linear speed of the torch, (ii) spraying distance, (iii) a solid content in the suspension, and (iv) way of preparing a substrate topography. Two different yttria stabilized zirconia powders were used to prepare suspensions: partially and fully stabilized respectively. These powders are now widely used in the industrial applications. Based on the microstructural studies an assessment was carried out if the Suspension Plasma Spraying can be an alternative method for the production of thermal barrier coatings to the processes applied currently.

Keywords: Suspension Plasma Spraying, Thermal Barrier Coatings, stabilized zirconia oxide, microstructure

\section{Wstęp}

Powłokowe bariery termiczne (ang. Thermal Barrier Coatings) stanowią jeden z kluczowych elementów rozwoju technologii związanych z turbinami gazo- wymi zarówno w silnikach samolotów jak również w elektrowniach. Głównym zadaniem powłokowej bariery cieplnej jest obniżenie maksymalnej temperatury na przekroju elementu do poziomu dopuszczalnego dla materiałów stosowanych na rdzeń elementu.

Mgr inż. Paweł Sokołowski, dr inż. Leszek Łatka, dr inż. Stefan Kozerski - Politechnika Wrocławska. 
Obecnie temperatura gazów spalinowych w turbinach dochodzi do wartości powyżej temperatury topnienia stosowanych materiałów, głównie stopów niklu z dodatkami chromu, aluminium oraz innych pierwiastków. Jej wartość przekracza $1500-1600^{\circ} \mathrm{C}$ i przewiduje się, że $\mathrm{w}$ dalszym ciągu będzie stale podnoszona w tempie około $15^{\circ} \mathrm{C} / \operatorname{rok}[1,2]$.

Jednak problemem są nie tylko wysokie temperatury, ale również jej gwałtowne zmiany w ciągu całego cyklu pracy turbin [3]. W czasie, kiedy turbina rozpoczyna lub też kończy pracę dochodzi do gwałtownych skoków temperatury powodujących występowanie $w$ materiale naprężeń cieplnych. Istotnym problemem jest również korozja spowodowana gorącymi gazami spalinowymi. Dokładna zawartość zanieczyszczeń zależy od rodzaju paliwa, powietrza oraz składu środka chłodzącego. Korozja wysokotemperaturowa $w$ turbinach spowodowana jest $w$ większości obecnością w spalinach związków siarki, wanadu czy też chlorku sodu [4,5]. Należy również pamiętać, że opisywane elementy poddawane są także działaniom dużym skokowym obciążeniom mechanicznym oraz procesom erozyjnym. Podczas pracy powierzchnia topatki nieustannie mają kontakt z produktami spalania, zanieczyszczeniami znajdującymi się w powietrzu, a nierzadko dochodzi również do sytuacji, kiedy do silnika dostanie się dużo większy obiekt. Wspomniane obciążenia czynią łopatki najbardziej obciążonym elementem turbin gazowych [3].

Mimo, bariery termiczne TBC bazujące na ceramice typu YSZ są stosowane już od 30-tu lat, zasadniczym problemem nadal jest ich trwałość. Zgodnie z przedstawionymi informacjami, łopatki turbin są elementem pracującym w niezwykle wymagających warunkach. Rosnące wymagania stawiane materiałom na powłoki TBC sprawiają, że dotychczas badane materiały i stosowane metody ich nakładania, m.in. konwencjonalne natryskiwanie plazmowe, nie pozwalają na uzyskanie odpowiednich parametrów użytkowych tych warstw. W związku z tym trwają intensywne prace badawcze nad nowymi rozwiązaniami. $Z$ jednej strony poszukiwane są nowe materiały (m.in. materiały na bazie tlenku cyrkonu stabilizowanego różnymi pierwiastkami ziem rzadkich - gadolin, lantan, cer etc.), z drugiej zaś rozwijane są technologie wytwarzania, które pozwolą na otrzymywanie powłok o podwyższonych własnościach $[6,7]$.

\section{Wytwarzanie współczesnych powłokowych barier cieplnych}

Kompletna powłoka TBC składa się z kilku warstw nałożonych na podłoże z superstopu niklu. Należy podkreślić, że każda z warstw powłoki charakteryzuje się różnymi właściwościami fizycznymi, mechanicznymi oraz cieplnymi. Podstawowym zadaniem podłoża jest przenoszenie obciążeń cieplno-mechanicznych. Kolejnym elementem układu jest międzywarstwa. Jej podstawową rolą jest zwiększenie przyczepności kolejnych warstw bariery cieplnej do podłoża oraz polepszenie własności eksploatacyjnych. Ponadto istotnym zadaniem warstwy podkładowej jest ochrona podłoża przed utlenianiem. Materiałem na międzywarstwę są przeważnie stopy na bazie niklu M-CrAlY (gdzie M stanowi: $\mathrm{Co}, \mathrm{Ni}$ lub CoNi) bądź też stopy Ni-Al. (aluminidki) [8]. Ta warstwa stanowi źródło aluminium dla leżącej na niej warstwy TGO. Jest to stosunkowo cienka (do $10 \mu \mathrm{m}$ ) warstwa (ang. Thermally Grown Oxide) zbudowana ze stabilnej odmiany tlenku aluminium $\left(\alpha-\mathrm{Al}_{2} \mathrm{O}_{3}\right)$. Jej podstawowym zadaniem jest zapewnienie ochrony przed utlenieniem podłoża [9]. Najważniejszą częścią powłokowej bariery cieplnej jest zewnętrzna warstwa ceramiczna, która powinna charakteryzować się niskim współczynnikiem przewodnictwa cieplnego, zapewniając dzięki temu izolację cieplną łopatki turbiny gazowej. Jako materiał na tę część układu TBC najczęściej stosuje się tlenek cyrkonu stabilizowany tlenkiem itru $\left(\mathrm{ZrO}_{2}+6 \div 8 \%\right.$ wag. $\left.\mathrm{Y}_{2} \mathrm{O}_{3}\right)$, znany powszechnie jako YSZ (ang. Yttria Stabilized Zirconia). Dodatek $\mathrm{Y}_{2} \mathrm{O}_{3}$ stabilizuje częściowo tetragonalną i regularna odmianę tlenku cyrkonu. Ponadto zapobiega on zmianom objętości, które wynikają z powstania fazy jednoskośnej [10]. Kompletny system powłokowej bariery cieplnej przedstawiono na rysunku 1 [11].
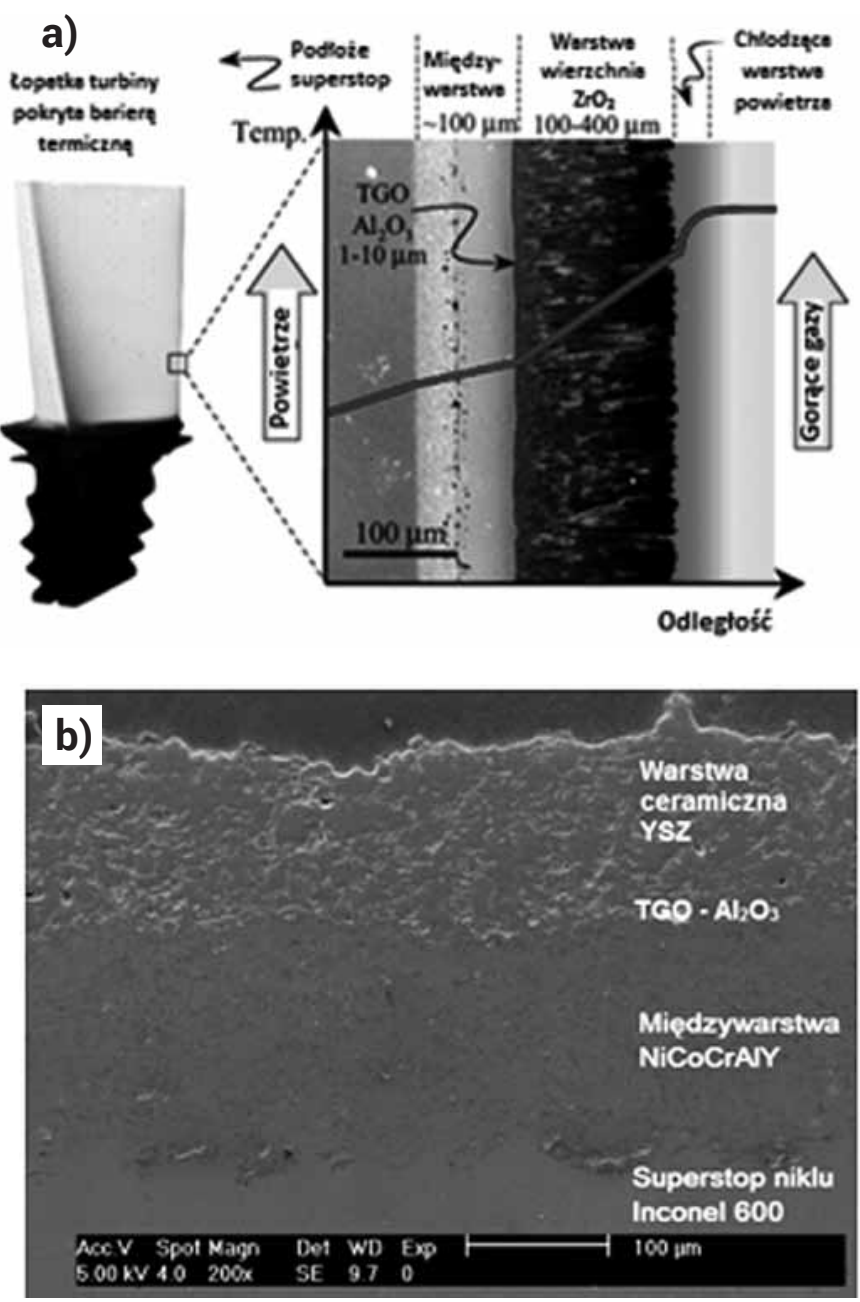

Rys. 1. Schemat obrazujący zasadę działania powłokowej bariery termicznej [11] a) oraz przekrój rzeczywistej powłoki TBC (opracowanie własne) b)

Fig. 1. Scheme presenting Thermal Barrier Coating system [11] a) and the micrograph of the cross-section of TBC coating 
Zewnętrzne powłoki ceramiczne są obecnie wytwarzane głównie metodą osadzania z fazy gazowej, np. z wykorzystaniem wysokoenergetycznej wiązki elektronowej EB-PVD oraz przez natryskiwania plazmowego głównie APS (rys. 2)[5].

Metoda EB-PVD pozwala uzyskać powłoki o bardziej optymalnych parametrach. Połączenie pomiędzy powłoką a podłożem ma na ogół charakter wiązań chemicznych. Powłoki EP-PVD wykazują większą odporność na utlenienie i korozję niż te natryskiwane metodą APS. Wyższa jest również odporność na szoki termiczne ze względu na kolumnowy układ struktury. Dodatkowo powierzchnia takiej powłoki jest bardziej jednolita, nie występuje problem zatykania otworów chłodzących oraz zachowany jest kształt łopatki. Ze względu jednak na wysoką cenę tego typu powłok zarezerwowane są one dla krytycznych elementów turbin. Pozostałe, ze względu na niższy koszt, natryskiwane są metodą konwencjonalnego natryskiwania plazmowego [12 $\div 15]$. Powłoki te są nie tylko tańsze, ale również ze względu na brak kolumnowej struktury wykazują lepszą izolacje cieplną. Dodatkowo możliwe jest ich wykonanie w szerokim zakresie grubości [16].
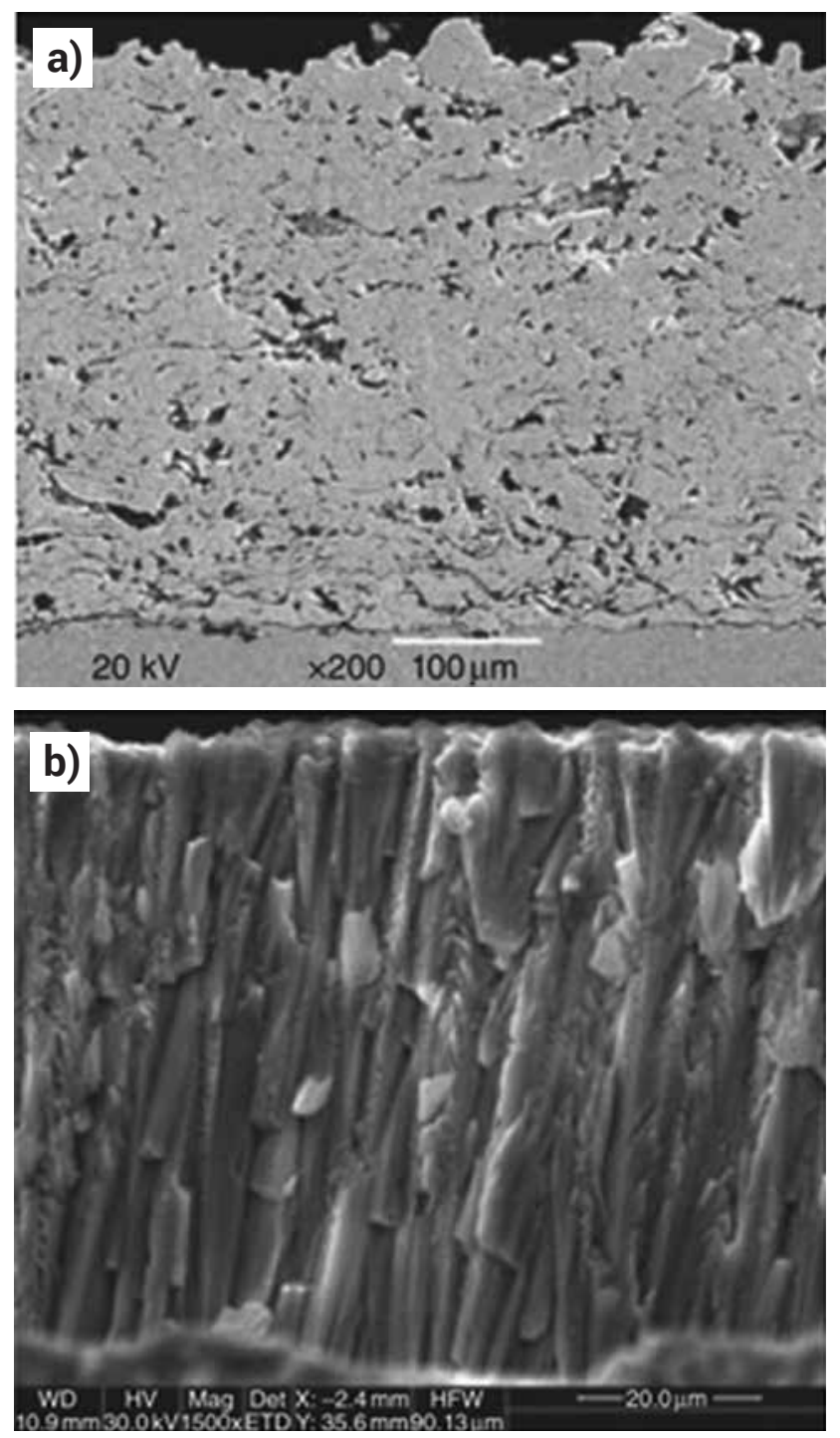

Rys. 2. Mikrostruktura powłoki naniesionej za pomocą EB-PVD(a) oraz APS(b) [5]

Fig. 2. The microstructure of ceramic coatings deposited by EBPVD(a) and APS(b) [5]
W ostatnich latach wprowadzono jednak nową, konkurencyjną względem EB-PVD oraz APS, metodę natryskiwania plazmowego z zawiesin (Suspension Plasma Spraying) [17]. Umożliwia ona wykonywanie powłok submikronowych, czy nanometrycznych, przy zachowaniu stosunkowo wysokiej efektywności procesu. Ponadto metoda SPS, ze względu na m.in. złożony przebieg procesu, umożliwia modyfikowanie struktury natryskiwanych powłok. Możliwe jest wytworzenie powłok m.in. bardzo porowatych, gęstych jak również powłok o bardzo korzystnym układzie porów prostopadłych do podłoża - tworzących strukturę pseudokolumnową. W dalszej części artykułu skupiono się na możliwościach przygotowania powłok ceramicznych metodą SPS różniących się pomiędzy sobą w znaczący sposób mikrostrukturą. $\mathrm{Na}$ podstawie badań mikrostruktury dokonano oceny potencjalnych możliwości zastosowań natryskanych powłok jako bariery cieplne.

\section{Opis eksperymentu}

\section{Przygotowanie proszku oraz zawiesiny}

W badaniach użyto dwóch różnych proszków ceramicznych na bazie tlenku cyrkonu stabilizowanego tlenkiem itru. Pierwszym z nich był proszek Metco 204NS o składzie chemicznym $\mathrm{ZrO}_{2}+8 \%$ wag. $\mathrm{Y}_{2} \mathrm{O}_{3}$. Jak wykazały badania przeprowadzone z użyciem dyfrakcji rentgenowskiej (Bruker, D8 Advance) proszek ten był częściowo stabilizowany. Analiza jakościowa (DiffracEva software) wykazała, że około 95\% wag. stanowiła faza tetragonalna, resztę natomiast faza jednoskośna. Ponadto ze względu na duży wymiar cząsteczek proszku konieczne było zmniejszenie jego wymiaru. W tym celu wykorzystano proces mielenia w młynie kulowym, gdzie jednorazowy wkład stanowit: (i) proszek, (ii) kule cyrkonowe, (iii) środek dyspergujący zapobiegający tworzeniu aglomeratów oraz (iv) etanol, jako medium chłodzące. W ten sposób z proszku o średnim rozmiarze cząsteczek $\mathrm{d}_{\mathrm{V} 50}=38 \mu \mathrm{m}$, uzyskano proszek submikrometryczny $\left(\mathrm{d}_{\mathrm{v} 50}=4,5 \mu \mathrm{m}\right)$ (Horiba, Partica LA-950V2). Wyjściowy proszek Metco 204NS oraz proszek po procesie mielenia zostały pokazany na rysunku 3 . Szczegółowe badania oraz informacje na temat przygotowywania proszku Metco 204NS do procesu natryskiwania zamieszczono w [18].

Drugim z użytych proszków był proszek tlenku cyrkonu TOSOH TZ-8YS o składzie chemicznym $\mathrm{ZrO}_{2}+14$ $15 \%$ wag. $\mathrm{Y}_{2} \mathrm{O}_{3}$ (rys. 4). Ze względu na wyższą zawartość tlenku itru proszek ten był w pełni stabilizowany i wykazywał strukturę regularną. Wymiary cząstek proszku były submikrometryczne, nie było więc konieczności przeprowadzenia dodatkowego mielenia proszku (średni rozmiar cząsteczek, $d_{v 50}=344 \mathrm{~nm}$ ) (Malvern, Zetasizer Nano ZS). Proszek Tosoh TZ-8YS został w pełni scharakteryzowany we wcześniejszych badaniach autorów [19].

Proces natryskiwania plazmowego z zawiesin w odróżnieniu od konwencjonalnego natryskiwania 

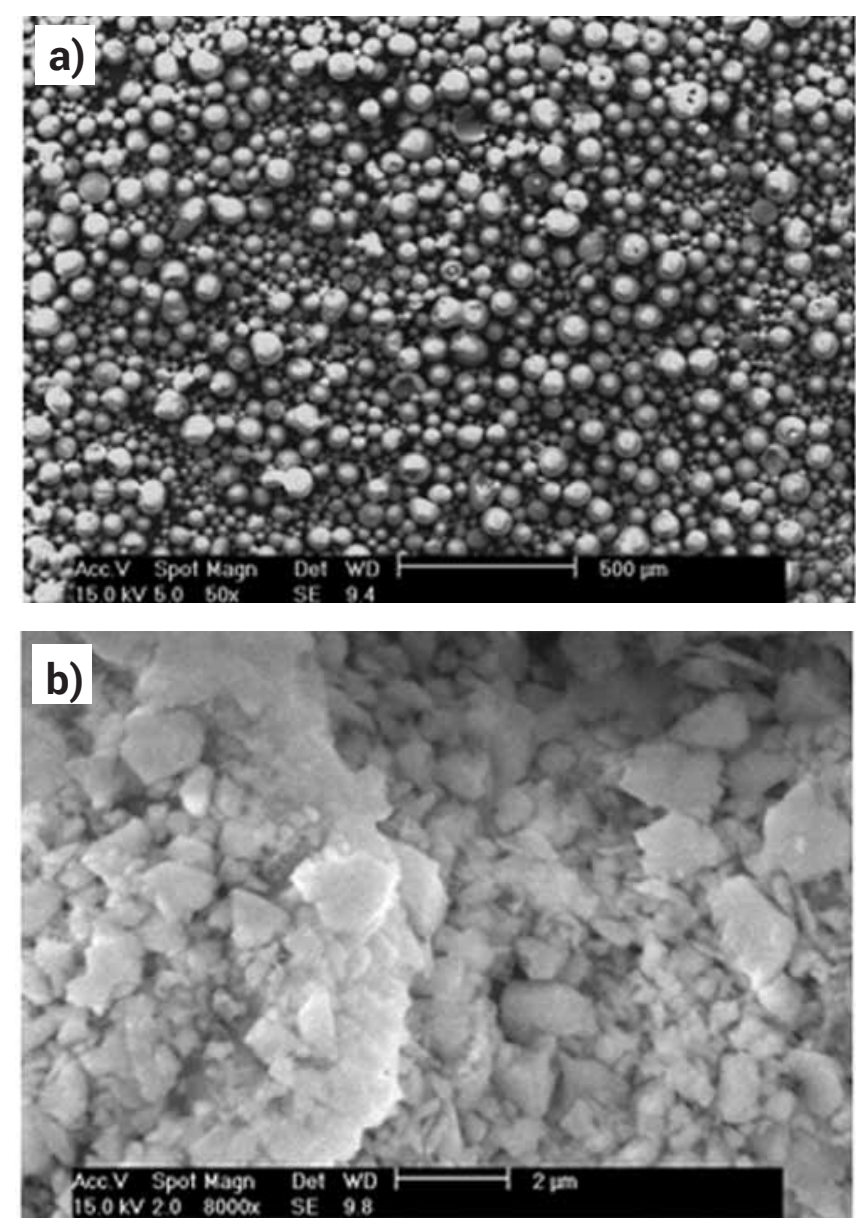

Rys. 3. Proszek Metco 204NS w stanie dostawy a) oraz proszek poddany procesowi mielenia w młynie kulowym b), SEM Fig. 3. Commercial Metco 204NS powder a) and powder after ballmilling process $b$ ), SEM micrographs

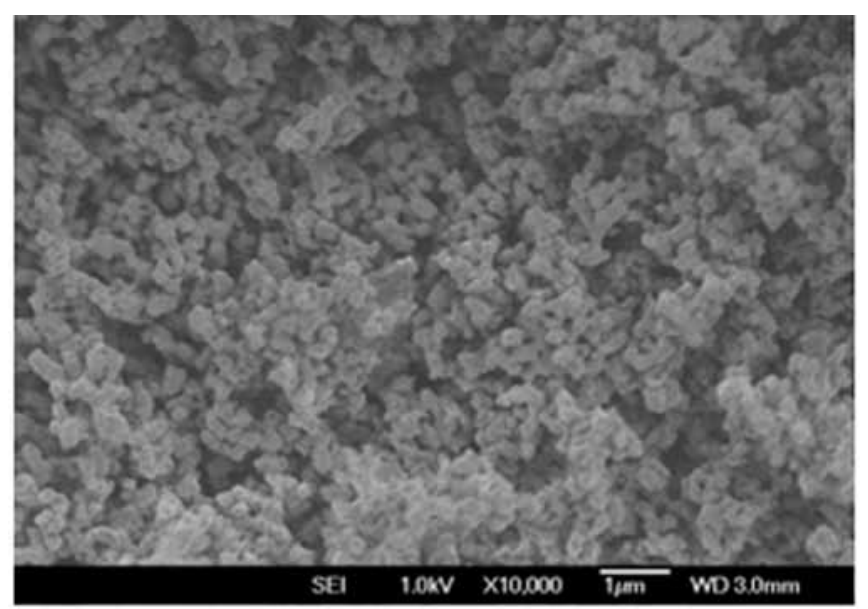

plazmowego charakteryzuje się tym, że zamiast wstrzeliwania w strumień plazmy suchego proszku podawana jest faza ciekła - zawiesina. Sposób przygotowania zawiesiny pokazano na rysunku 5 .

W procesie natryskiwania zostały wykorzystane zawiesiny na bazie dwóch wcześniej opisanych proszków. W obu przypadkach oprócz fazy stałej zawiesina składała się z wody destylowanej oraz etanolu w stosunku 1:1 z dodatkiem środka dyspergującego (Beycostat C213- ester fosforanowy) zapobiegającego aglomerowaniu cząstek proszku.

\section{Proces natryskiwania}

W celu natryskiwania powłok wykorzystano stanowisko wyposażone w palnik plazmowy SG-100 (Praixair S.T., Indianapolis, USA) z wewnętrznym, promieniowym, układem wtryskiwania zawiesiny. Został on zamontowany na ramieniu pięcioosiowego robota IRB-6 (ABB, Zürich, Switzerland), który skanował powierzchnię nieruchomych próbek. Podłoża stalowe, na których osadzono powłoki zamontowane były na płaskim stole z wykorzystaniem pompy próżniowej. W czasie natryskiwania prowadzono bezdotykowy pomiar temperatury powierzchni próbek z wykorzystaniem pirometru. Powierzchnia próbek oraz stół były chłodzone w czasie natryskiwania sprężonym powietrzem.

Proces natryskiwania przeprowadzony został dwukrotnie. W pierwszym etapie badań wykorzystano mielony proszek Metco 204NS, zawiesinę zawierającą $20 \%$ wag. fazy stałej oraz dwupoziomowy pełny plan eksperymentu (2k), gdzie zmiennymi parametrami były: (i) prędkość liniowa palnika (od 300 do $500 \mathrm{~mm} / \mathrm{s}$ ) oraz (ii) dystans pomiędzy palnikiem i powierzchnią próbki (od 40 do $60 \mathrm{~mm}$ ). W kolejnym etapie badań wykorzystano proszek Tosoh TZ8-YS o znacznie mniejszym wymiarze cząsteczek. Natomiast zmiennymi w procesie były: (i) zawartość fazy stałej (proszku) w zawiesinie (odpowiednio 2,5; 5; $10 \%$ wag.) oraz (ii) sposób przygotowania podłoża stalowego (piaskowanie, szlifowanie, obróbka laserowa). W obu przypadkach zastosowano tą samą kompozycją gazów plazmowych (40 l/min argonu + $5 \mathrm{l} / \mathrm{min}$ wodoru) oraz moc elektryczną wynoszącą 40kW. Szczegółowe dane na temat planowania opisywanych eksperymentów można znaleźć w $[18,19]$.

Rys. 4. Proszek Tosoh TZ-8YS, SEM

Fig. 4. The microstructure of Tosoh TZ-8YS powder, SEM

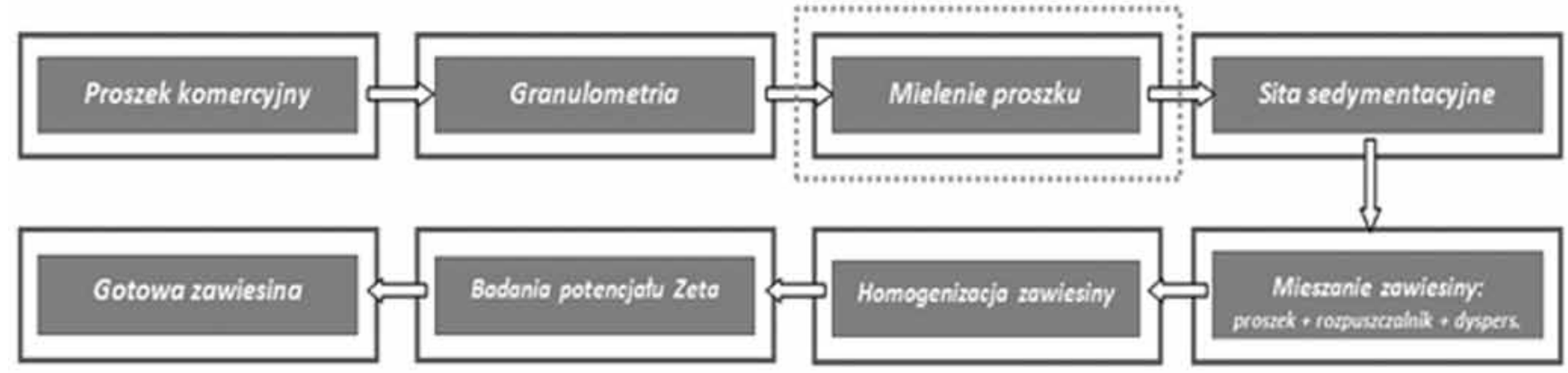

Rys. 5. Schemat prezentujący przygotowywanie zawiesiny do procesu natryskiwania plazmowego z zawiesin

Fig. 5. Suspension preparation procedure prior to Suspension Plasma Spraying process 
Tablica I. Zestawienie parametrów w procesie natryskiwania Table I. Design of the spray process

\begin{tabular}{|c|c|c|c|c|c|c|}
\hline Eksperyment & Proszek & $\begin{array}{c}\text { Prędkość liniowa } \\
\text { palnika, mm/s }\end{array}$ & $\begin{array}{c}\text { Odległość } \\
\text { natryskiwaia, } \mathrm{mm}\end{array}$ & $\begin{array}{l}\text { Ilość fazy stałej } \\
\text { w zawiesinie, \% }\end{array}$ & $\begin{array}{c}\text { Przygotowanie } \\
\text { podłoża }\end{array}$ & $\begin{array}{c}\text { Oznaczenie } \\
\text { próbki }\end{array}$ \\
\hline \multirow{5}{*}{1} & Metco 204NS & 300 & 40 & 20 & Piaskowanie & YSZ-1 \\
\hline & Metco 204NS & 500 & 40 & 20 & Piaskowanie & YSZ-2 \\
\hline & Metco 204NS & 400 & 50 & 20 & Piaskowanie & YSZ-3 \\
\hline & Metco 204NS & 300 & 60 & 20 & Piaskowanie & YSZ-4 \\
\hline & Metco 204NS & 500 & 60 & 20 & Piaskowanie & YSZ-5 \\
\hline \multirow{9}{*}{2} & Tosoh & 500 & 40 & 2,5 & Piaskowanie & ST21 \\
\hline & Tosoh & 500 & 40 & 2,5 & Obróbka laserowa & ST22 \\
\hline & Tosoh & 500 & 40 & 2,5 & Szlifowanie & ST23 \\
\hline & Tosoh & 500 & 40 & 5 & Piaskowanie & ST51 \\
\hline & Tosoh & 500 & 40 & 5 & Obróbka laserowa & ST52 \\
\hline & Tosoh & 500 & 40 & 5 & Szlifowanie & ST53 \\
\hline & Tosoh & 500 & 40 & 10 & Piaskowanie & ST101 \\
\hline & Tosoh & 500 & 40 & 10 & Obróbka laserowa & ST102 \\
\hline & Tosoh & 500 & 40 & 10 & Szlifowanie & ST103 \\
\hline
\end{tabular}

\section{Mikrostruktura powłok}

Szczegółowe obserwacje mikrostruktury powłok zostały przeprowadzone wykorzystując skaningową mikroskopię elektronową z zastosowaniem elektronów wtórnych (Philips XL30).

$\mathrm{Na}$ przekrojach poprzecznych powłok wytworzonych zgodnie z pierwszym planem eksperymentu (rys. 6a-8a) widoczne są dobrze przetopione lamele, pomiędzy którymi jednak zaobserwowano pory. Porowatość w otrzymanych powłokach wynosiła od 8 do $12 \%$ [18]. Z kolei na powierzchniach badanych powłok (rys. 6b-8b) ujawniono obecność tzw. dwustrefowej mikrostruktury, [20]. Jest ona złożona z dobrze przetopionych ziaren (lameli) oraz bardzo drobnych, kulistych cząstek, w formie spieczonych aglomeratów. Taka mikrostruktura jest charakterystyczna dla powłok natryskiwanych plazmowo z zawiesin $[18,21]$.

Mikrostruktura powłok wytworzonych według drugiego planu eksperymentu została przedstawiona

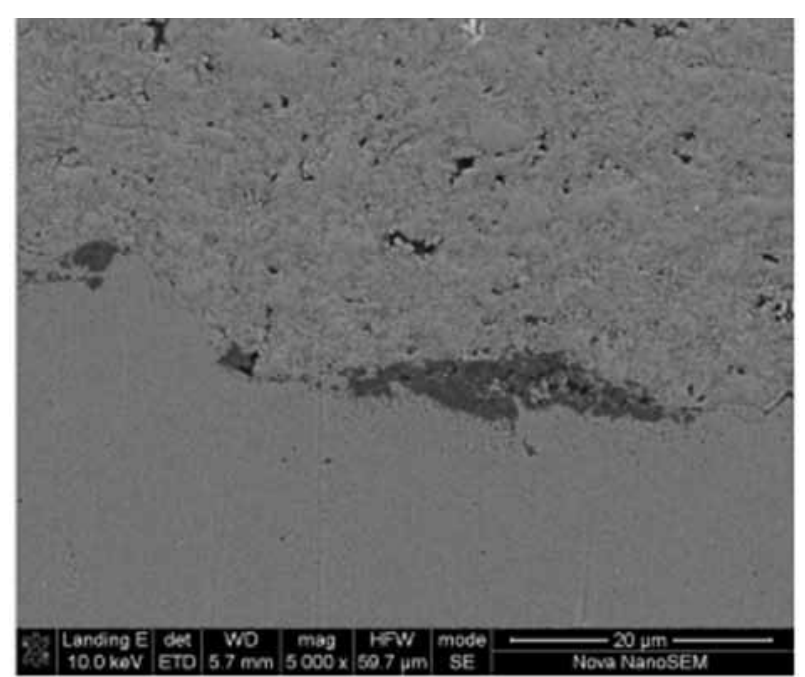

na rysunkach 9:11. Można zauważyć, że poprzez zmianę zawartości proszku oraz sposób przygotowania podłoża możliwe było modyfikowanie mikrostruktury powłok w bardzo znaczący sposób. Wytworzone powłoki charakteryzowały się zmienną budową wewnętrzną, porowatością, czy topografią powierzchni. Stwierdzono, że wraz ze wzrostem zawartości fazy stałej w zawiesinie zmniejszał się udział porów w strukturze powłok (od 21 do 15\%) [19], a struktura i topografia powłok stawały się bardziej jednorodne. Z kolei sposób przygotowania podłoża determinował w głównej mierze budowę wewnętrzną powłok. W przypadku powłok wytworzonych na podłożu poddanym obróbce laserowej możliwie było zaobserwowanie struktury pseudokolumnowej. Z kolei standardowe przygotowanie powierzchni poprzez obróbkę strumieniowo-ścierną powodowało formowanie typowej dwustrefowej struktury powłok, w szczególności, kiedy zawartość proszku w zawiesinie była wysoka. Powierzchnia powłok w znaczący sposób odzwierciedlała natomiast sposób przygotowania podłoża przed procesem natryskiwania (rys.10b).

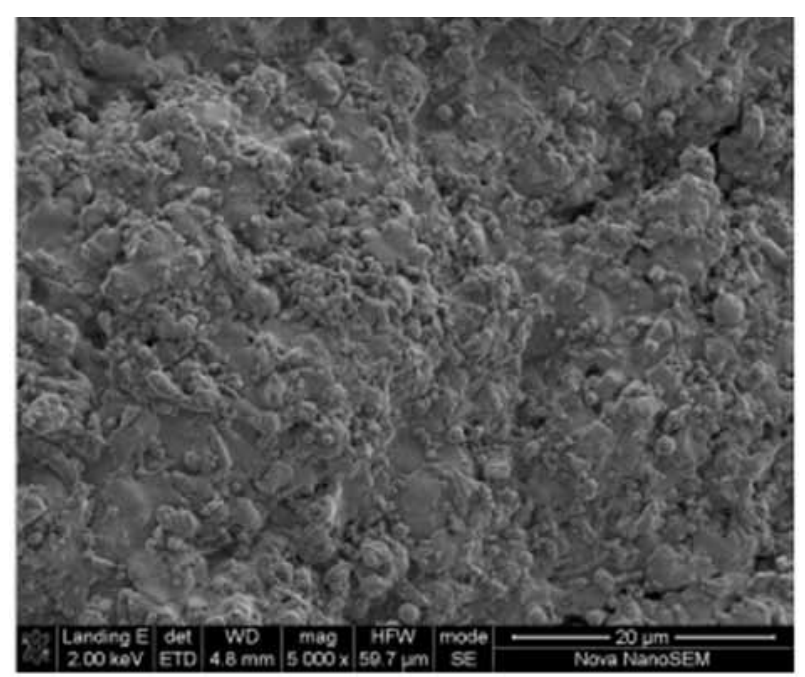

Rys. 6. Powłoka YSZ-1: (a) przekrój poprzeczny, (b) powierzchnia; SEM (elektrony wtórne)

Fig. 6. YSZ-1 coating: (a) cross-section, (b) surface; SEM (SE mode) 

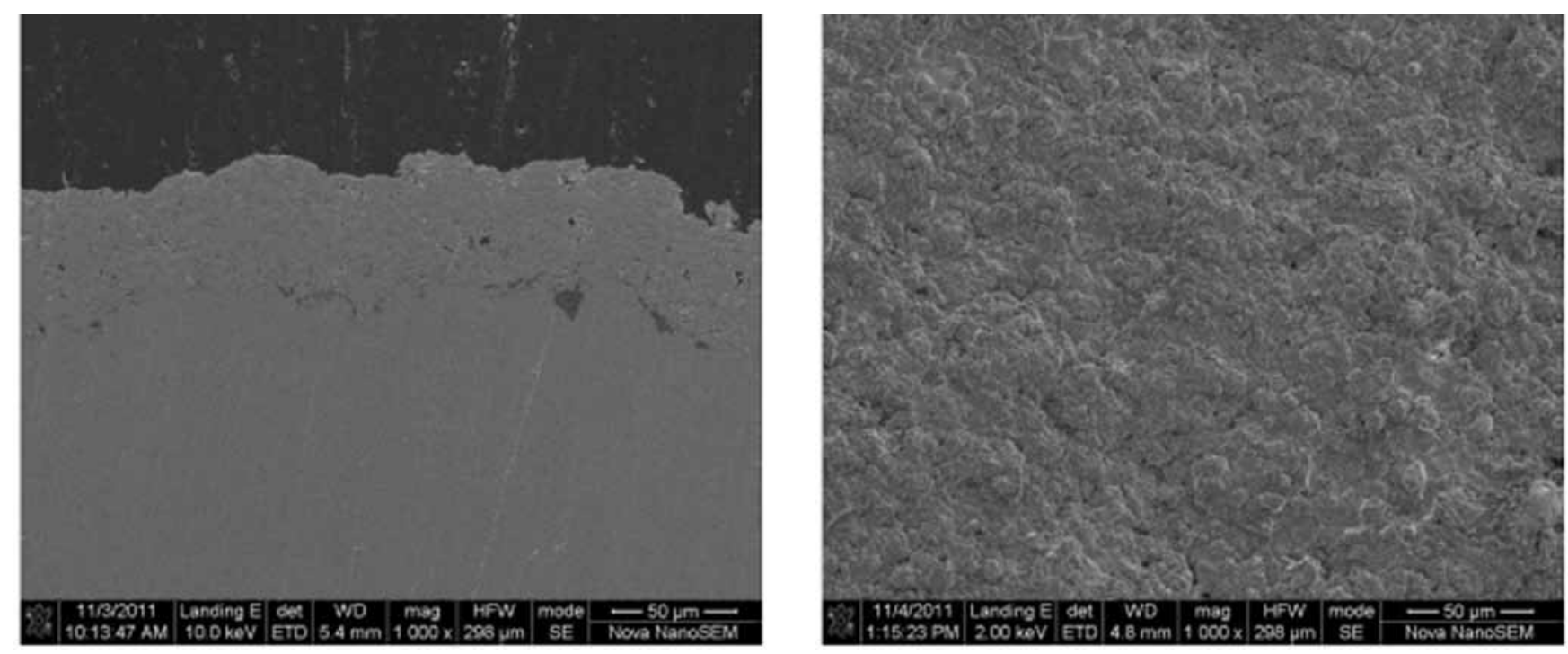

Rys. 7. Powłoka YSZ-3: (a) przekrój poprzeczny, (b) powierzchnia; SEM (elektrony wtórne)

Fig. 7. 7 YSZ-3 coating: (a) cross-section, (b) surface; SEM (SE mode)
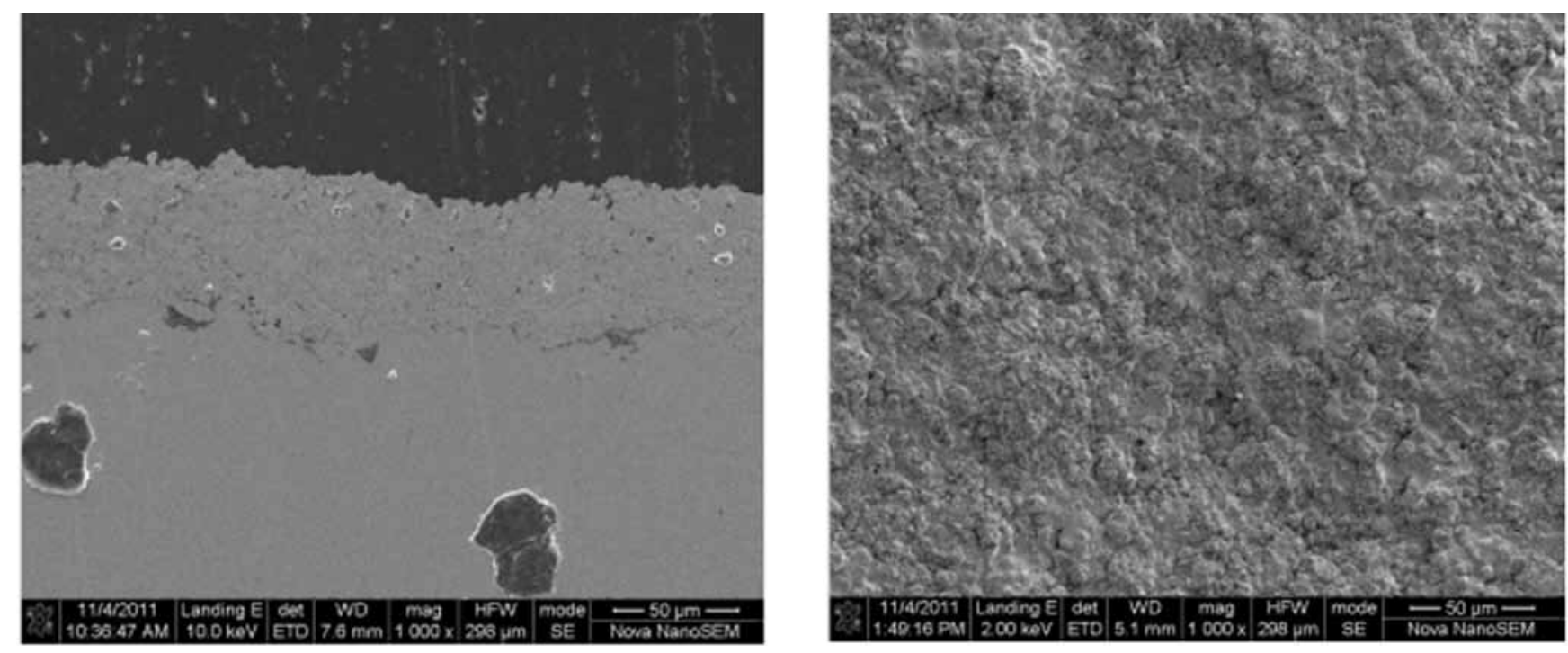

Rys. 8. Powłoka YSZ-5: (a) przekrój poprzeczny, (b) powierzchnia; SEM (elektrony wtórne)

Fig. 8. YSZ-5 coating: (a) cross-section, (b) surface; SEM (SE mode)
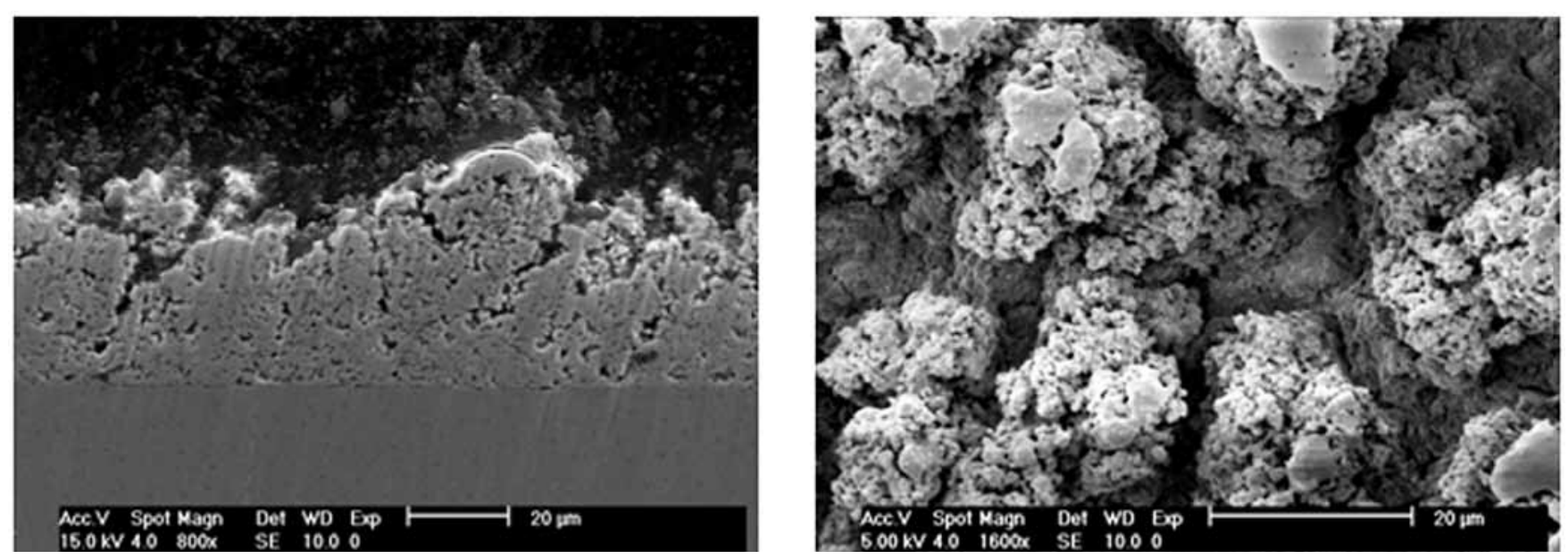

Rys. 9. Powłoka ST23: (a) przekrój poprzeczny, (b) powierzchnia; SEM (elektrony wtórne))

Fig. 9. ST23 coating: (a) cross-section, (b) surface; SEM (SE mode) 

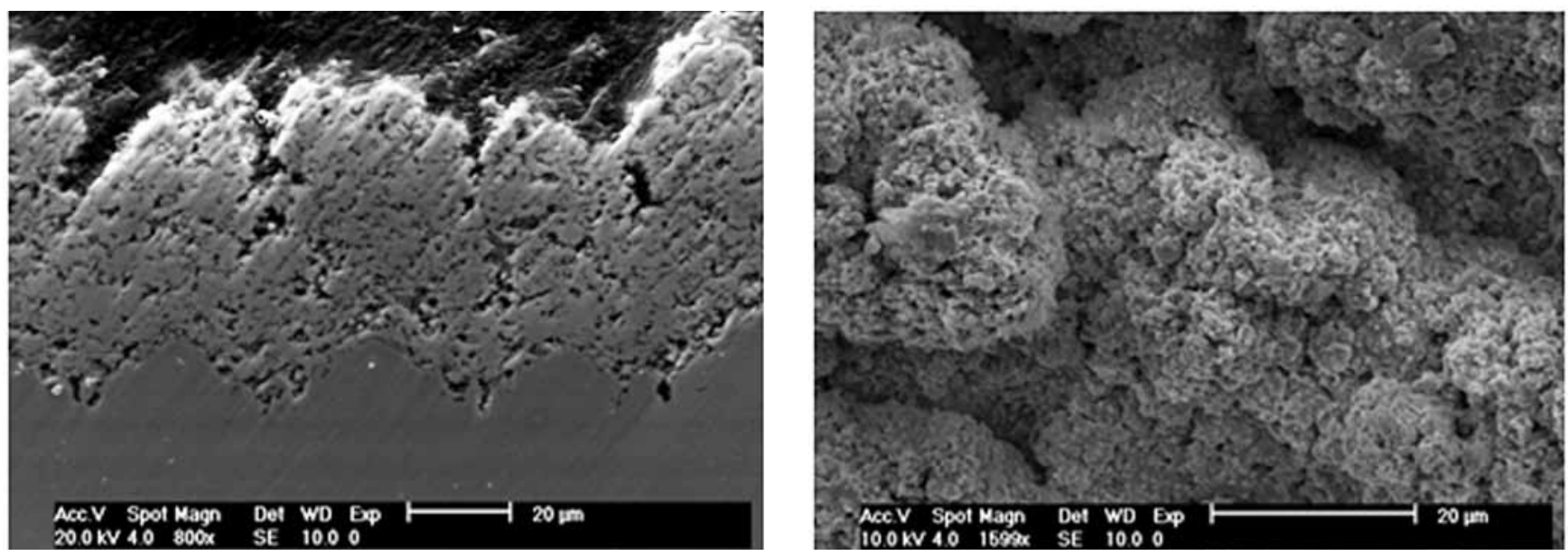

Rys. 10. Powłoka ST52: (a) przekrój poprzeczny, (b) powierzchnia; SEM (elektrony wtórne)

Fig. 10. ST52 coating: (a) cross-section, (b) surface; SEM (SE mode)
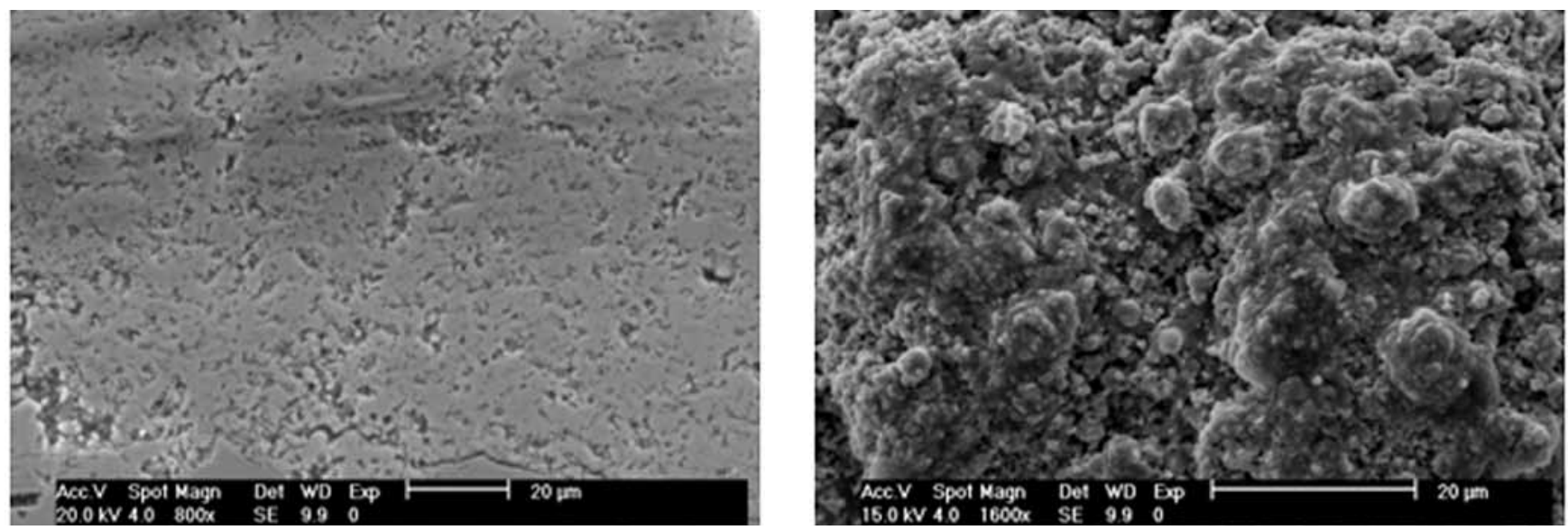

Rys. 11. Powłoka ST101: (a) przekrój poprzeczny, (b) powierzchnia; SEM (elektrony wtórne)

Fig. 11. ST101 coating: (a) cross-section, (b) surface; SEM (SE mode)

\section{Dyskusja wyników}

$\mathrm{Na}$ podstawie pierwszego z przeprowadzonych eksperymentów, gdzie zmiennymi parametrami były liniowa prędkość palnika względem podłoża oraz odległość natryskiwania, można zaobserwować wyraźny ich wpływ na mikrostrukturę. Zauważono, że zbyt wysoka temperatura podczas nanoszenia powłok (mała prędkość i mała odległość) powodowała pęknięcia, których przyczyną były zbyt wysokie naprężenia cieplne. Z drugiej strony charakterystyczna dwustrefowa struktura powłok charakteryzująca się stosunkowo dużą porowatością (o rozmiarach mikrometrycznych i submikrometrycznych) powodują obniżenie wartości przewodności cieplnej, co korzystnie wpływa na możliwość zastosowania tych powłok na bariery cieplne.

$Z$ kolei zastosowanie $w$ drugim planie eksperymentu proszku o mniejszym rozmiarze cząsteczek, wykorzystanie zawiesiny o różnej zawartości fazy stałej, a także odpowiednie przygotowanie podłoża pozwoliło w znaczny sposób modyfikować strukturę otrzymanych powłok. Powłoki charakteryzowały się przede wszystkim różną budową wewnętrzną. Z jednej strony możliwe było zaobserwowanie, typowych dla natryskiwania plazmowego z zawiesin, dwustrefowych struktur charakteryzujących się występowaniem obszarów przetopionych lameli oraz drobnych spieczonych cząsteczek proszku. Mikrostruktura tych powłok, charakteryzująca się regularnym rozłożeniem drobnych porów w strukturze, jest szczególnie interesująca ze względu na korzystne własności cieplne. Nieciągłości powłoki w skuteczny sposób blokują przepływ ciepła, dlatego też powłoki te stanowią bardzo dobre zabezpieczenie powierzchni metalicznych przed wysoką temperaturą. Z drugiej strony odnotowano, że dzięki zastosowaniu drobnego proszku oraz przygotowaniu podłoża o regularnej topografii powierzchni, np. poprzez obróbkę laserową, możliwe jest wytworzenie struktury pseudokolumnowej. Struktura ta, ze względu na m.in. dużo niższe naprężenia wewnętrze w powłoce, jest bardzo korzystna ze względu na wysoką odporność na cykliczne zmiany temperatury (szoki termiczne). Należy jednak pamiętać, że podłużne, prostopadłe do powierzchni podłoża, pory nie stanowią bariery dla przepływu ciepła zwiększając przewodność cieplną i tym samym narażają powierzchnię na większe obciążenia cieplne. Kompromis pomiędzy wspomnianymi parametrami jest bardzo istotny dla wytrzymałości całego układu TBC i wydaje się, że znalezienie go jest możliwe $z$ wykorzystaniem metody natryskiwania plazmowego z zawiesin poprzez możliwość modyfikacji struktury wytwarzanych powłok. 


\section{Podsumowanie}

Przeprowadzone badania miały na celu określić możliwość wykorzystania metody natryskiwania plazmowego z zawiesin (Suspension Plasma Spraying) do wytwarzania zewnętrznej warstwy ceramicznej w systemie powłokowej bariery cieplnej. Głównym kryterium, jakie przyjęto do opisu przydatności metody natryskiwania z zawiesin (SPS) była mikrostruktura powłok, która jak powszechnie wiadomo determinuje późniejsze własności użytkowe. W celu przygotowania powłok wykorzystano złożony plan eksperymentu, który obejmował wykorzystanie dwóch proszków stabilizowanego tlenku cyrkonu, a także różnych parametrów procesu takich jak: (i) prędkość liniowa palnika, (ii) odległość natryskiwania, (iii) zawartość fazy stałej w zawiesinie oraz (iv) sposób przygotowania podłoża.
Przeprowadzone badania mikrostruktury wykazały, że $\mathrm{w}$ zależności od zastosowanych parametrów procesu możliwe było wytworzenie powłok o zróżnicowanej mikrostrukturze. Otrzymane powłoki charakteryzowały się różną porowatością (od bardzo porowatych do stosunkowo gęstych), czy topografią powierzchni. Kluczowym osiągnięciem było jednak otrzymanie powłok o różnej budowie wewnętrznej - zarówno powłok charakteryzujących się typową dwustrefową strukturą jak i powłok o budowie pseudokolumnowej. Poprzez możliwość modyfikacji struktury powłok możliwe jest w znaczącym stopniu modyfikowanie ich własności użytkowych. $\mathrm{Na}$ tej podstawie stwierdzono, że natryskiwanie plazmowe z zawiesin może być bardzo znaczącą alternatywą dla metod stosowanych obecnie (EB-PVD czy APS) w celu wytworzenia zewnętrznej powłoki ceramicznej w powłokowych barierach cieplnych.

\section{Literatura}

[1] F.R. Martínez, A.A.R. Martínez, M.T. Velázquez, P.Q. Diez, G.T. Eslava, J.A. Francis: Evaluation of the Gas Turbine Inlet Temperature with Relation to the Excess Air, Energy and Power Engineering, 2011, 3, s. 517-524.

[2] E. Campo, V. Lupinc: High Temperature Structural Materials for Gas Turbines, Conference of Innovative Materials, IMAT 92, Modena, 1992

[3] Roberts T.: The Structure and Stability of High Temperature Intermetallic Phases for Application within Coating Systems, PhD Thesis, Cranfield University, November 2009.

[4] A.S. Khanna, S.K. Jha.: Degradation of materials under hot corrosion conditions, Trans. Indian Inst. Met. 51 (5) (1988) s. $279-290$.

[5] H. Xu, H. Guo: Thermal barrier coatings, Woodhead Publishing Limited, 2011.

[6] T.B. Hazel, D.A. Litton, M.J. Maloney, U.S. Patent No. US20130260132, 2013.

[7] J. Larose, US Patent No. 2014/0017477 A1, 2014.

[8] R.C. Reed: The superalloys: fundamentals and applications, Cambridge University Press, UK, 2006.

[9] G. Evans, D. Clarke, C. Levi: The influence of oxides on the performance of advanced gas turbines, Journal of the European Ceramic Society, 28 (2008), s. 1405-1419.

[10] R. Swadźba, J. Wiedermann, R. Rozmus: Analiza mikrostruktury powłokowych barier cieplnych TBC po teście cyklicznego utleniania w temperaturze $1100^{\circ} \mathrm{C}$, Prace Instytutu Metalurgii Żelaza, 3 (2013), s. 29-34.

[11] P. Nitin Padture, Maurice Gell, E.H. Jordan: Thermal Barrier Coatings for Gas-Turbine Engine Applications, Science, Vol. 296 Issue 5566, s. 280-284, 2002.

[12] R.A. Miller. Current status of thermal barrier coatings - an overview, Surf. Coat. Technol., 30 (1987), s. 1-11.
[13] M. Gell, G. Vaidyanathan, B. Barber, et al.: Mechanism of spallation in platinum aluminide/electron beam physical vapour deposited thermal barrier coatings, Metall. Trans., 30A (1999), s. 427-435.

[14] D.J. Wortman, B.A. Nagaraj, E.C. Duderstadt: Thermal barrier coatings for gas turbine use, Mater. Sci. Eng. A, 121 (1989), s. 433-440.

[15] Z. Tang, H. Kim, I. Yaroslavski, G. Masindo, Z. Celler, D. Ellsworth: Novel Thermal Barrier Coatings Produced by Axial Suspension Plasma Spray, Proceedings of International Thermal Spray Conference and Exposition, 2011, Hamburg, Germany.

[16] D.J. Wortman, B.A. Nagaraj, E.C. Duderstadt: Thermal barrier coatings for gas turbine use, Mater. Sci. Eng. A, 121 (1989) 433-440.

[17] F. Gitzhofer, E. Bouyer, M.I. Boulos: Suspension plasma spraying, US Patent 5609 921, 3 November 1997.

[18] L. Łatka, A. Cattini, L. Pawłowski, S. Valette,B. Pateyron, J.P. Lecompte, R. Kumar, A. Denoirjean: Thermal diffusivity and conductivity of yttria stabilized zirconia coatings obtained by suspension plasma spraying, Surface and Coatings Technology, 208 (2012) s. 87-91.

[19] P. Sokołowski, S. Kozerski, L. Pawłowski, A. Ambroziak: The key process parameters influencing formation of columnar microstructure in suspension plasma sprayed zirconia coatings, Surface and Coatings Technology, Volume 260, 2014, s. 97-106.

[20] Kozerski S., Pawłowski L., Jaworski R., Roudet F., Petit F., Two zones microstructure of suspension plasma sprayed hydroxyapatite coatings, Surface and Coatings Technology, 204 (2010) 1380-1387.

[21] S. Kozerski, L. Łatka, L. Pawłowski, F. Cernuschi, F. Petit, C. Pierlot, H. Podlesak, J.P. Laval: Preliminary studies on suspension plasma sprayed $\mathrm{ZrO}_{2}+8 \mathrm{wt} . \% \mathrm{Y}_{2} \mathrm{O}_{3}$ coatings, Journal of the European Ceramic Society, 31 (2011), s. 2089-2098. 